Scientific Journal of October 6 University

ISSN (Print): 2314-8640

ISSN (Electronic): 2356-8119

Published by October 6 University @ All Rights Reserved

Available online at: http:// sjou.journals.ekb.eg

Original Article
Citation: Abdel-Maksoud et al., (2016). Biochemical changes associated with Helicobacter Pylori infection Sci. J. of Oct. 6 Univ. 3(2), 8-12.

Copyright: (C) 2016 Abdel-Maksoud et al. This is an open-access article distributed under the terms of the Creative Commons Attribution License, which permits unrestricted use, distribution, and reproduction in any medium, provided the original author and source are credited.

\title{
Biochemical Changes Associated with Helicobacter pylori Infection
}

\author{
Abdel-Maksoud H.A ${ }^{1}$, Frarah $K^{2}$, Raafat R. Gendi ${ }^{3}$ and Metwaly $\mathbf{M}^{1}$ \\ ${ }^{1}$ Bioch. Dep. Fac. . Vet. Med. Moshtohor, Benha Uni., Egypt. \\ ${ }^{2}$ Clinical Patho. Dep, Fac. Vet. Med. Moshtohor, Benha Uni., Egypt. \\ ${ }^{3}$ Fellow and Researcher in Bioch. Hosp.Central Lab. Fac. Med.Benha Uni.
}

Received: 25-03-2016/ Revised: 1-04-2016 / Accepted: 3-05-2016

\begin{abstract}
This study was performed to investigate the biochemical alteration of Biochemical effects of Helicobacter pylori infection on iron metabolism and its related components in human. Ninety Patients (male \& female) were divided according to ages into four groups; the group (I) contained 20 healthy individuals aged (10 - 65) years used as control for all groups. Group (II): consisted from 30 infected patients with Helicobacter pylori aged (10 $-25)$ years. Group (III): consisted from 30 infected patients with Helicobacter pylori aged (25 - 40) years. Group (IV): consisted from 30 infected patients with Helicobacter pylori aged (40-65) years.

The blood samples were collected and the obtained results revealed that, Significant increases in serum gastrin amylase, ammonia, total iron binding capacity (TIBC), transferrin, total cholesterol, triacylglycerols (Tg), low density lipoprotein-cholesterol (LDL), very low density lipoprotein-cholesterol (VLDL), high density lipoprotein-cholesterol (HDL) Furthermore, significant decreases were in plasma serum iron, Ferritin, haptoglobin, Vitamin $\mathrm{B}_{12}$, leptin and HDL in compared to control group. From the obtained results it could be concluded that, we must take car from Helicobacter pylori.
\end{abstract}

Key Words: Helicobacter pylori, ammonia, haptoglobin, Vitamin $\mathrm{B}_{12}$ and leptin.

\section{Introduction}

At the end of the last century $H$. pylori was appeared with reports from several investigators who observed helicobacter in the human and mammalian stomach (Abdel-Shafeik, 2015). Acute infection with $H$. pylori during childhood can be accompanied by diarrhea and slowing of weight gain (Konno et al., 2005). Helicobacter pylori, is a Gram a negative curved $\mathrm{S}$ shaped rod colonizes in the stomach with a worldwide spreading. More than $50 \%$ of the world's populations are infected with higher prevalence in developing countries (Brown, 2000). The possibility that some H. pylori strains have a specific ability to interfere with iron metabolism seems unlikely as neither virulence factors nor mutations in the bacterial genes involved in iron uptake have been demonstrated to be associated with it Choe et al., ( 2010). Recent study provides increase in prevalence of it among infected persons such as Berg et al., (2010) suggesting that $H$. pylori produces anemia by altering iron metabolism. Overall, the study suggests that $H$. pylori may cause micro bleeding and /or affect iron uptake and thus deplete iron stores in persons with IDA, independently of ulcer disease (Victor 2006). Population-based studies demonstrated a strong relationship between serum ferritin levels and presence of IgG anti $H$. pylori (Berg 2001). The aim of the present study is to show the biochemical alterations of serum iron , Ferritin , Haptoglobin ; Amylase ; Ammonia ; Leptin ; Gastrin ; Vitamin $\mathrm{B}_{12}$ and Lipid Profile (Cholesterol, T.G, HDL, LDL, and VLDL) in patients with Helicobacter pylori infection .

\section{Study Design}

The study taken out on: A- 20 healthy person as control group; B- 90 patients infected with H.pylori, with age range between 25 and over 65 years, patients was selected from Gamal Abdel Naser General Hospital in medicine and endemic medicine departments for treatment from continuous (pyloric burning) heart burning and upon analysis them blood samples for the presence of H.pylori antibodies they are positive. In the present study, the four groups classified according to age into four equal groups as follow:

Group I: Control healthy individuals consist of 20persons with ages ranged from 10 to over 65 year.

*Corresponding Author Address: Prof. Abdel-Maksoud H.A: Bioch. Dep. Fac. . Vet. Med. Moshtohor, Benha Uni., Egypt

E-mail: abdelmaksoud@yahoo.com 
Group II: Consisted from 30-diseased patients with age ranged from 10 to 25 years.

Group III: Consisted from 30-diseased patients with age ranged from 25-40 years.

Group IV: Consisted from 30-diseased patients with age ranged from 40 to 65 years.

\section{Blood sampling:}

Blood samples were collected from every patient whole blood was obtained in the sterile tubes for complete agglutination to obtaining serum. Then the blood samples were centrifuged at $3000 \mathrm{rpm}$ for 10 minutes. The clear specimens were aspirated carefully by Pasteur pipettes and transferred into dry, clean and sterile labeled tubes.

Then, the following biochemical parameters were analysis was performed for the following parameters:-

Biochemical parameters are:

- Plasma Ammonia ( Neeley and Philipson 1988).

- Serum Amylase (Garaway et al.,1959).

- Lipid profile Total cholesterol (Fossati and principle 1982), HDL-C ( Allain et al.,1974), LDLC (Falholt et al., 1973),VLDL-C (Friedewald 1973) and Triacylglycerol (Bucolo and David, 1973).

- Serum Gastrin (Goetze and Rehfeld 2003).

- Serum leptin (Titez 1995).

- Serum iron (Henry 1974), Ferritin (Valberg 1980), total Iron Binding Capacity (TIBC) (Nissen, 1972), Transferrin (Fairbanks and Klee 1987) and serum Haptoglobin (Johnson et al.,1999).

-Serum Vitamin $\mathrm{B}_{12} \quad$ (Sadasivam and Balasubraminan, 1987).

- H.pylori antibodies determined by one step (Marshall et al, 1985).

\section{Statistical analysis:}

Statistical analysis of the result was carried out using student's T-test.Data were expressed as mean \pm S.E. and were statistically analyzed according to Steel and Torrie (1980).

\section{Results}

The present data revealed that $H$. pylori infection associated with low iron stores and anemia gave a reason for these unexplained cases of iron deficiency anemia (IDA), its infection, with or without gastric cells atrophy, should always be considered a possible cause of IDA (David 2005), A correct diagnosis is relevant for the management of the patient as this is the only GI cause of IDA potentially curable with a medical treatment (Dickey 2002). The study of (Ashorn 2004), provides increase in prevalence of IDA among $H$. pylori infected persons due to it produces an altering in iron metabolism. Overall, the study suggests that $\mathrm{H}$. pylon may cause micro bleeding and/or affect iron uptake and thus deplete iron stores in persons with IDA, independently of ulcer disease. Recent population-based studies demonstrated a strong relationship between serum ferritin levels and presence of $\mathrm{IgG}$ anti H. pylori (Victor et al., 2006).

\section{Biochemical parameters Table (1):}

The result revealed that significant increase in Ammonia in group III and group IV, and significant increase in Amylase in group IV as compared with the control group, while the Vitamin $B_{12}$ was significantly decrease in group III and highly significant decrease in group IV as compared to control group.

\section{Hormonal parameters Table (2):}

Showed significant increase in serum gastrin in group II and highly significant increase in groupIII and groupVI as compared to the control group.On the other hand there was significant decrease in serum Leptin in group III and groupIV on comparison to the control group.

\section{Lipid profile parameter Table (3):}

Showed significant increase in T.C in group III, IV in addition LDL-C level in group III showed highly significant increase in LDL-C level in group IV and non significant increase in VLDL-C level. While it significantly decreased in HDL-C in group IV when compared to the control group.

\section{Iron status parameters Table (4)}

There was significant decrease in serum iron level in group IV and in ferritin level in group II, III .while there was highly significant decrease in ferritin in group IV as compared to the control group. On the other hand, there was significant increase in transferrin in group III, IV and TIBC in group II and there was highly significant increase in TIBC in group III and IV on comparison with the healthy group.

\section{Discussion}

The obtained data in tables indicated that the recorded increase in plasma ammonia in $\mathrm{H}$. Pylori infection can be generated by the urease activity of H. pylori in the gastric mucosa, which accounts for more than $6 \%$ of overall bacterial proteins Le Veen et al., (2004). Also, Queiroz et al., (2006) found that $H$. pylori infection is associated with elevated blood ammonia and the eradication of $H$. pylori may reduce the blood ammonia levels in cirrhotic patients.

The notices significant increase in serum amylase activities came in agreement with the recorded data of Jaworek et al., (2000), who found that, Gastric infection with $H$. pylori caused gastric 
pathologies, also it able to determine systemic effects and diseases with increasing evidence that $H$. pylori infection affected the pancreas so increases amylase activities

The significant increases in serum cholesterol, T.G, LDL, VLDL in group II, group III and group IV as compared with group I (Control); and decreased HDL in group II, group III and group IV are due to the positive correlation between $\mathrm{H}$. pylori infection and the risk of cardiovascular disease Franceschi et al(2009), Gen et al., (2010), whereas others have not confirmed such findings Khairy et al., (2013). The significant increase in serum gastrin level when comparing each of the infected groups with the control one, and also when comparing its level in group II with that in group III; and also when comparing its level in group III with that in group IV, are because of the age at which this bacterium is acquired seems to influence the possible pathologic outcome of the infection - people infected at an early age are likely to develop more intense inflammation that may be followed by atrophic gastritis with a higher risk of gastric ulcer, gastric cancer or both. Acquisition at an older age brings different gastric changes that are more likely to result in duodenal ulcer. Individuals infected with $H$. pylori have a 10 to $20 \%$ lifetime risk of developing peptic ulcers and a 1 to $2 \%$ risk of acquiring stomach cancer (Kusters et al., 2006).

The Significant decrease in serum Leptin in group II, group III and group IV as compared with group I (Control) which is an adipocyte-derived hormone that causes reduced food intake and BMI, has also been shown to be present in the gastric mucosa, where the decreased gastric leptin level with gastric epithelial injuries caused by $H$. pylori infection, as stated by (Gholamreza et al. 2013) who showed that, $H$. pylori infection may influence leptin production. Advanced age might expose the individual to $H$. pylori infection and consequently influence the leptin level. The study we could not find an association between $H$. pylori infection and high serum leptin levels. It might be assumed that H.pylori infection may alter gastric leptin levels through inducing injuries on gastric mucosa and consequently leptin producing cells, leading to decline of circulating leptin level.

The Significant decrease in serum iron in group II, group III and group IV as compared with group I (Control) is an essential micronutrient for both animals and microorganisms and is a cofactor for enzymes involved in oxygen transport, DNA synthesis and electron transport (Conrad and Umbreit, 2010).

Whereas Janjetic et al., (2010) study revealed that $H$ pylori infection was not associated with iron deficiency, anemia, or zinc concentrations; however, a positive relation with copper status was found after adjusting for confounding factors.

The Significant increase in TIBC in group II, group III and group IV as compared with Control group agreed with Park et al., (2010) stated that, H. pylori infection decreases RBC indices and serum iron and increases TIBC in children. These changes become prominent as age increases. This age effect may be related to the duration of $H$. pylori infection. The significant increase in serum transferrin in group II, group III and group IV as compaired with group I (Control) which is a bloodderived component. In gastrointestinal bleeding diseases, it may be leaked into gastrointestinal tract and then discharged with the stool. Transferrin is stable in faeces and a good marker to detect gastrointestinal bleeding. This immunochrom atographic assay detects simultaneously $H$. pylori and human transferrin in stool samples, obtaining more accurate testing results regarding the $H$. pylori infection (Abdel- Shafeik 2015).

Our results showed that an increase in Transferrin which agree with Choe et al., (2009) and Keramati et al., (2007), who revealed that, Since the prevalence of both $H$. pylori infection and iron deficiency are high. Our results in Table (1) show significant decrease in serum Vitamin $B_{12}$ in group II, group III and group IV as compared with group I (Control) this decrease is agree with the data of Khedmat et al., (2013) who suggested a correlation between vitamin $\mathrm{B}_{12}$ deficiency in CKD patients and the HP infection status. Due to $H$. pylori gastritis leads to the impairment of the production of pepsinogen and acid which are essential to cobalamin absorption Brusa et al., (2004).

The significant decrease in serum Haptoglobin in group II, group III and group IV as compaired with group I (Control) indicate that this protein in humans is encoded by the HP gene as proved by ( Wassell 2010).

In contrast, Saremi et al., (2012) stated that Haptoglobin levels that are decreased but do not accompany signs of anemia may indicate liver damage, as the liver is not producing enough haptoglobin to begin with. Test protocol Haptoglobin is ordered whenever a patient exhibits symptoms of anemia.

\section{Conclusion}

H.pylori infection associated with increased ammonia, amylase and Gastrin level which are associated with precipitate hepatic encephalopathy, pancreatic disease and gastric cancer. Also, this infection change serum lipid concentration, increasing the risk of atherosclerosis and ischemic heart disease $H$. pylori is probably responsible of IDA (iron deficiency anemia) and pernicious anemia through several mechanisms and affect regulation of appetite. 
Table 1. Effect of Helicobacter pylori infection on plasma ammonia, serum amylase,Vitamin $B_{12}$ and haptoglobin.

\begin{tabular}{|c|c|c|c|c|}
\hline $\begin{array}{c}\text { Parameter } \\
\text { groups }\end{array}$ & $\begin{array}{c}\text { Ammonia } \\
(\mathbf{U m o l} / \mathbf{L})\end{array}$ & $\begin{array}{c}\text { Amylase } \\
(\mathbf{U} / \mathbf{L})\end{array}$ & $\begin{array}{c}\text { Vitamine B12 } \\
(\mathbf{P g} / \mathbf{m L})\end{array}$ & $\begin{array}{c}\text { Haptoglobulin } \\
\mathbf{( g / L )}\end{array}$ \\
\hline G I & $45.80 \pm 2.11$ & $88.50 \pm 1.79$ & $194.51 \pm 4.53$ & $137.181 \pm 4.11$ \\
\hline G II & $51.80 \pm 1.91$ & $76.5 \pm 1.87$ & $115.00 \pm 2.97$ & $110.81 \pm 3.12$ \\
\hline G III & $63.19 \pm 2.21^{*}$ & $96.0 \pm 2.81$ & $101.11 \pm 3.12^{*}$ & $97.61 \pm 3.11$ \\
\hline G IV & $86.89 \pm 2.75^{*}$ & $126.0 \pm 4.11^{*}$ & $91.78 \pm 3.11^{* *}$ & $91.8 \pm 2.71 * *$ \\
\hline
\end{tabular}

Mean $\pm 5.6,{ }^{*} P<0.05$ means significant, ${ }^{*} * P<0.01$ means highly significant

Table (2): Effect of Helicobacter pylori infection on serum Gastrin and plasma leptin.

\begin{tabular}{|l|l|l|}
\hline $\begin{array}{l}\text { Parameter } \\
\text { groups }\end{array}$ & $\begin{array}{l}\text { Gastrin } \\
\text { (ng/L) }\end{array}$ & $\begin{array}{l}\text { Leptin } \\
\text { (ng/L) }\end{array}$ \\
\hline G I & $71.00 \pm 1.91$ & $6.51 \pm 0.93$ \\
\hline G II & $120.11 \pm 3.96^{*}$ & $4.91 \pm 0.77$ \\
\hline G III & $125.0 \pm 4.75^{* *}$ & $4.02 \pm 0.87^{*}$ \\
\hline G IV & $133.65 \pm 4.15^{* *}$ & $3.81 \pm 0.88^{*}$ \\
\hline
\end{tabular}

$* P<0.05$ means significant, $* * P<0.01$ means highly significant

Table (3): Effect of Helicobacter pylori infection on serum lipid profile parameters.

\begin{tabular}{|c|c|c|c|ccc|c|}
\hline $\begin{array}{c}\text { Parameter } \\
\text { groups }\end{array}$ & $\begin{array}{c}\text { T-C } \\
(\mathbf{m g} / \mathbf{d l})\end{array}$ & $\begin{array}{c}\text { Tg } \\
(\mathbf{m g} / \mathbf{d l})\end{array}$ & $\begin{array}{c}\text { HDL-C } \\
(\mathbf{m g} / \mathbf{d l})\end{array}$ & $\begin{array}{c}\text { LDL- C } \\
(\mathbf{m g} / \mathbf{d l})\end{array}$ & $\begin{array}{c}\text { VLDL-C } \\
(\mathbf{m g} / \mathbf{d l})\end{array}$ \\
\hline G I & $148.00 \pm 3.11$ & $101.51 \pm 1.91$ & $41.60 \pm 1.81$ & $86.10 \pm 2.58$ & $20.30 \pm 0.82$ \\
\hline G II & $168.15 \pm 4.12$ & $128.50 \pm 3.81$ & $35.33 \pm 0.97$ & $107.12 \pm 2.59$ & $25.70 \pm 0.76$ \\
\hline G III & $189.85 \pm 3.35^{*}$ & $143.51 \pm 4.25$ & $30.77 \pm 2.75$ & $130.38 \pm 2.93 *$ & $28.70 \pm$ & 0.85 \\
\hline Group IV & $218.41 \pm 4.50^{*}$ & $149.18 \pm 3.87$ & $30.10 \pm 2.75^{*}$ & $158.50 \pm 3.51^{* *}$ & $29.84 \pm 0.78$ \\
\hline
\end{tabular}

$* P<0.05$ means significant, $* * P<0.01$ means highly significant

Table (4): Effect of Helicobacter pylori infection on iron status parameters.

\begin{tabular}{l} 
Table (4): Effect of Helicobacter pylori infection on iron status parameters. \\
\begin{tabular}{|c|c|c|c|c|}
\hline $\begin{array}{l}\text { Parameter } \\
\text { groups }\end{array}$ & Iron (Ug/dl) & Ferritin (ng/dL) & TIBC (Ug/dL) & Transferrin (\%) \\
\hline G I & $145.8 \pm 3.75$ & $211.81 \pm 6.51$ & $255.8 \pm 6.11$ & $2.93 \pm 0.08$ \\
\hline G II & $102.75 \pm 3.01$ & $121.91 \pm 3.33^{*}$ & $286.8 \pm 5.81 *$ & $3.16 \pm 0.12$ \\
\hline G III & $95.89 \pm 3.11$ & $118.81 \pm 2.8 *$ & $311.00 \pm 6.80 * *$ & $3.69 \pm 0.23 *$ \\
\hline G IV & $90.81 \pm 2.80 *$ & $93.8 \pm 1.86 * *$ & $336.70 \pm 7.81 * *$ & $4.18 \pm 0.52 *$ \\
\hline
\end{tabular}$* P<0.05$ means significant, $* * P<0.01$ means highly significant \\
\hline
\end{tabular}


$\underline{\text { References }}$

Abdel- Shafeik SA. (2015). " Biochemical changes associated with Helicobacter Pylori infection " Mas. Degree in Bioch. Fac. Vet.Med. Damanhour Univ.

Allain CC, Poon LS, Chan CS, Richmond W, Fu C (1974). Enzymatic determination of total serum cholesterol. .Clin chem. 4:470-475

Ashorn M, Ruuska T, Makipernaa A. (2001). Helicobacter pylori and iron deficiency anaemia in children. Scand $\mathbf{J}$ Gastroenterol; 36: 701-5.

Ashorn M. (2004). Acid and iron-disturbances related to Helicobacter pylori infection. J Pediatr. Gastroenterol . Nutr; 38: 137-39.

Berg G, Bode G, Blettiner M (2010). Helicobacter pylori infection and serum ferritin: a population based study among 1806 adults in Germany. Am J Gastroenterol ; 96:1014-19.

Brown LM (2000). Helicobacter pylori: epidemiology and routes of transmission. Epidemiol. Rev.; 22:283-297.

Brusa L, Pietroiusti A, Pierantozzi M, Galato S, Fedele E, Stazione P. (2004). Long-term effects of helicobacter pylori eradication on L-dopa absorption in Parkinson's Disease Patients. Move Disord. 19(9):S387.

Bucolo G, David H (1973). Quantitative determination of serum triglycerdes by the use of enzymes, Clin Chem ;19(5):476-82

Choe YH, S K. Kim, B K Son, DH Lee, YC Hong, S.H. Pai (2009). "Randomized placebo-controlled trial of Helicobacter pylori eradication for iron-deficiency anemia in preadolescent children and adolescents." Helicobacter 4(2): 135-139.

Conrad, M. E. and J. N. Umbreit (2010). "Iron absorption and transport-an update." Am J Hematol 64(4): 287-298.

Choe Y H, YS. Kwon, MK. Jung, S. K. Kang, T. S. Hwang and Y. C. Hong (2010). "Helicobacter pylori-associated irondeficiency anemia in adolescent female athletes." $J$ Pediatr 139(1): 100-104.

David J Kearney. (2005). Helicobacter pylori infection and iron deficiency anemia: accumulating evidence in support of a real association. Indian Journal of Gastroenterology, 24: 14750.

Dickey W. (2002). Iron deficiency, gastric atrophy and Helicobacter pylori. Dig Liver Dis; 34: 313-15.

Falholt K., Falholt W., Lund B. (1973). An easy colorimetric method for routine determination of free fatty acids in plasma. Clin Chim Acta, 46:105-111.

Fairbanks VF, Klee G. (1987). Biochemical aspects of heamatology.In textbook of clinical chemistry; InW.titez,Ed.Philadelphia,W.B.Saunders Company,PP 15781582.

Fossati P, Prencipe L. (1982). Serum triacylglycerols determined colorimetrically with an enzyme that produces hydrogen peroxide. Clin Chem. 1: 2077-2080.

Franceschi F, Navarese E, Mollo R, Giupponi B, De Marco G, Merra G, Gasbarrini G, Silveri NG (2009). Helicobacter pylori and Atherosclerosis. A Review of the Literature. Recent Progressi in Medicine, 100, 91-96.

Friedewald WT. (1973 ) Estimation of concentration of lowdensity lipoprotein cholesterol in plasma without use of the preparative ultracentrifuge. Clin Chem. 18: 499-502

Garaway WT, Ame J (1959) Amylase determination method.Clin Pathol 32,97-99.

Gen, R., Demir, M. aAtaseven, H. (2010) Effect of Helicobacter pylori Eradication on Insulin Resistance, Serum Lipids and Low-Grade Inflammation. Southern Medical Journal, 103, 190-196.

Gholamreza Hemmasi, Farhad Zamani, Mahmoodreza Khonsari, Masoudreza Sohrabi, Nafiseh Abdollahi, Hossein Ajdarkosh , ( 2013). Association between Helicobacter pylori and Serum Leptin in Iranian Dyspeptic Patients. Middle East $J$ Dig Dis. 5(3): 158-162.

Goetze J, Rehfeld JF(2003). Impact of Assay Specificity in Gastrinoma Diagnosis. Clin Chem; 49;333-334.

Henry RJ (1974). Clinical Chemistry ,Principles and techniques,2nd ed., Harper and Row:543-695.

Janjetic MA, Goldman CG, Balcarce NE, Rua EC, González AB (2010) Iron, zinc and copper nutritional status in children infected with Helicobacter pylori. J Ped Gastroenterology Nut 51: 85-89.

Jaworek J, Bilski J, Jachimczak B, Cieszkowski M, Kot M, Bielanski W, Konturek SJ. (2000). The effects of ammonia on pancreatic enzyme secretion in vivo and in vitro. J Physiol Pharmacol. 51:315-32.

Johnson, AM, Rohlfs EM, Silverman LM (1999). proteins .In: Burrtis CA, Ashwood ,E.R.,eds.Tietz Text-book of clinical chemistry. Philadelhia:WB Saunders Company ,477-540.

Keramati MR. Siadatz, M. (2007) The Correlation Between H. pylori Infection with Serum Ferritin Concentration and Iron Deficiency Anemia International Journal of Hematology and Oncology. 17: 456-459.

Khairy, P., Rinfret, S., Tardif, J.C., Marchand, R., Shapiro, S., Brophy, J., et al. (2013) Absence of Association be- tween Infectious Agents and Endothelial Function in Healthy Young Men. Circulation, 107, 1966-1971.

Khedmat H, Amini M, Karbasi A, Azizi R. (2013). The effect of Helicobacter pylori on vitamin B 12 blood levels in chronic renal failure patients: a single blind control trial Saudi J Kidney Dis Transpl. 2013 Jul;24(4):759-63.

Konno M, Fujii N, Yoko\& S, Takahashi M, Sato K, Mino E, Sugiyama T.( 2005 ) Five years follow-up study of mother-tochild transmission of Helicobacter pylori infection detected by a random amplified polymorphic DNA fingerprinting method. J Clin Microbiol; 43: 2246-50.

Kusters JG, AH van Vliet, E. J. Kuipers (2006). "Pathogenesis of Helicobacter pylori infection." Clin Microbiol Rev 19(3): 449-490.

LeVeen HH, LeVeen EG, LeVeen RF (2004) Awakenings to the pathogenicity of urease and the requirement for continuous long Manes G Balzano A Vaira D (2003) Helicobacter pylori and Pancreatic Disease JOP. J Pancreas (Online) 2003; 4(3):111-116

Marshall ,B.J., Gechie, M., Rogers, D.B., and Glancy ,R.G.(1985). Pyloric Campylobacter infection and gastroduodenal disease .Med.J.Australia.149:439-44.

Neeley WE, Phillison J. (1988) Automated enzymatic method for determining ammonia in plasma, with 14-day reagent stability.Clin Chem..1988 sep; 34(9):1868-9.

Nissen M (1972). Colorimetric method for determination of Total iron binding capacity (TIBC).Clin. Chim Acta. 40:219-224. Park SJ, Lee CH, Chung KS. (2010). Red Blood Cell Indices, Serum Iron and Total Iron Binding Capacity in Children with Helicobacter pylori Infection Korean $J$ Pediatr (2000) June;43(6) :755-762

Queiroz DM, Rocha AM, Rocha GA, (2006) : Association between Helicobacter pylori infection and cirrhosis in patients with chronic hepatitis C virus. Dig Dis Sci 2006; 51:370-373.

Sadasivam,S., and Balasubraminan, T.(1987) In :Practical Manual in Biochemistry Tamil Nadu Agricultural University Coimbatore $\mathrm{p} 14$

Saremi B, Al-Dawood A, Winand S, Müller U, Pappritz J, von Soosten D, Rehage J, Dänicke S, Häussler S, Mielenz M, Sauerwein H (May 2012). "Bovine haptoglobin as an adipokine: Serum concentrations and tissue expression in dairy cows receiving a conjugated linoleic acids supplement throughout lactation". Vet Immunol Immunopathol. 146 (3-4): 201-11.

Steel RGD, Torrie JH (1980) Principles and Procedures of statistics,Second Edition, New York: McGraw-Hill Book Co.

Titez, N.W. (1995) Clinical guide to laboratory tests. 3rd ed .philadelphia:WB saunders,268-273.

Valberg,L.(1980). Plasma ferritin concentration, their clinical significance and relevance to patient care.J.Canda. MedicineAssiciation, 122:1240-1247

Wassell J (2010). "Haptoglobin: function and polymorphism". Clin. Lab. 46 (11-12): 547-52.

Victor M. Cardenas Zuber D. Mulla Melchor Ortiz, David Y. Graham. (2006). Iron Deficiency and Helicobacter pylori Infection in the United States. Am J Epidemiol; 163: 127-34. 